\title{
Exploring the Consumer Impulse Buying Behaviour from a Range of Consumer and Product Related Factors
}

\author{
Abraham Yeboah $^{1} \&$ Vida Owusu-Prempeh ${ }^{2}$ \\ ${ }^{1}$ Department of Marketing, Sunyani Technical University, Sunyani, Ghana \\ Correspondence: Abraham Yeboah, Faculty of Business and Management Studies, Sunyani Technical University, \\ Sunyani, Ghana. E-mail: yeboah.a@stu.edu.gh
}

Received: February 20, 2017 Accepted: March 9, 2017 Online Published: March 10, 2017

doi:10.5539/ijms.v9n2p146 URL: http://doi.org/10.5539/ijms.v9n2p146

\begin{abstract}
The main purpose of this study is to explore the consumer impulse buying behaviour from a range of consumer and product related factors. To achieve this purpose, the study was guided by five research questions in the area of product physical quality, product price, product attractiveness, product origin, and purchase location. The study employed quantitative method. A sample of 179 respondents (consumers) that visited the Accra Shopping Mall was employed using convenient selection method. A self-completed 5 point Likert structured questionnaire survey was the data collection instrument used. The data collected were computed and analysed with reliability statistics, Cramer's V statistics under a crosstabulation statistical technique test to determine the association between the variables involved in this study. Overall, findings indicate that, the association between consumer impulse buying behaviour and product physical quality, product price, product attractiveness, product origin and purchase location was not strong. Consequently, each of the five products related factors shows a weak association with consumer impulse buying behaviour. It is recommended that manufacturers and other stakeholders support retail shops in diverse methods to improve upon their selling techniques and new ways to appeal to consumers.
\end{abstract}

Keywords: consumer behaviour, impulse buying behaviour, antecedent of impulse buying, range of consumer, product related factors

\section{Introduction}

In recent years, it has been observed that consumers take into considerations several factors when making consumption buying decisions whether planned or unplanned. In the light of this, consumers are exposed to a number of retail activities designed by shop owners to put up for sale, such as effective door-to-door selling, sales on-credit arrangement and so on. It is further observed that consumers buy products unplanned, consequently impulsive buying is in the ascendency nowadays.

In a research by Cobb and Hoyer (1986), the consumer impulse buying has generated arguments among various disciplines and researchers in recent decades. In view of this, it is found that the study of consumer buying behaviour in the aspect of impulse buying came to light 40 years ago and regarded as a significant form of consumer consumption buying behaviour. A similar research, Rook and Fisher (1995) discovered that consumer consumption impulse buying behaviour is examined nearly 50 years, and a related study, Iris (2002) showed that consumers buying product(s) impulsively have been actually a very rare behaviour. Additionally, American Marketing Association (1969) stated that the consumer in-store buying behaviour has become important in relation to impulse purchasing behaviour. However, Rook (1987) discovered that, the American consumers' has been mainly attributed to consumption impulse buying in relation to their lifestyles. In other study, Stern (1962) identified a number of factors influenced consumers to impulsively buy products - such as cultural, time and personality. Also, D'Antoni and Shenson (1973a) discovered that cultural, chronological, personal and locational factors usually motivate consumer impulse buying behaviour. Among study, Tauber (1972) found a number of reasons which encourage consumers' consumption shopping behaviour than the main need to buy products. Additionally, Hoch and Loewenstein (1991) found that circumstances regarding consumers' inconsistent mood in relation to a point in time impacted on impulse purchasing decisions. Other study by Klaus (1998) showed that consumers' lack of self-control is found to be influenced by the consumer impulse buying behaviour in relation to individual decision and desires. More so, D'Antoni and Shenson (1973b) claimed that consumers attempting 
to minimise perceived risk significantly encourages impulse buying decisions, such as given free-sample of product, money-back-guarantees, trail moments and so on. In spite of this, Kacen and Lee (2002) revealed that consumers buying impulsively represent over $\$ 40$ billion on sales volume contributed to the America economy. That not with standing, Silvera, Lavack and Kropp (2008) found the element of compulsive buying related to impulse buying that engenders the consumer consumption impulse buying decision. In a study by Rook (1987) revealed that the consumer impulse buying behavior is associated with marketing and sales, retail innovations, for instance credit cards, cash machines, instant credit and 24-hour retail activities, which encourages consumers to buy impulsively on the products at any given point-in-time which make it much easier.

On the whole, it is relevant to suggest that study into the product related factors on impulse buying has received unclear attention across various past studies in the related disciplines, particularly in the marketing field. Based on this, much attention is required, and this study seeks to concentrate and contribute to advanced knowledge about consumer impulse buying behaviour by produced empirical findings that are relevant in the marketing, as well as to inform manufacturers, retail practitioners, social policy, who want to enhance their understanding on impulsive buying behaviour. The overall purpose of this study is to explore the consumer impulse buying behaviour from a range of consumer and product related factors. In order to achieve the purpose of the study, the following research questions were formulated.

1). What is the association between the consumer impulse buying behaviour from a range of consumer and product physical quality?

2). What is the association between the consumer impulse buying behaviour from a range of consumer and product price?

3). What is the association between the consumer impulse buying behaviour from a range of consumer and product attractiveness?

4). What is the association between the consumer impulse buying behaviour from a range of consumer and product origin?

5). What is the association between the consumer impulse buying behaviour from a range of consumer and purchase location?

The next sections discuss a review of existing literature on impulse buying behaviour. This will be followed by the methodology of the study under evaluation and discussion of results. The final part discusses results of the study in relation to previous empirical findings.

\section{Literature Review}

\subsection{Theoretical and Empirical Perspective of Impulse Buying Behaviour}

Basically, studying impulse buying behaviour is debated in several ways. This involves whether consumers buy products impulsively at all. Apart from this, issues that affect the consumer impulse buying behaviour have also been debated. That notwithstanding, there is a controversy surrounding impulse buying as unplanned buying. In spite of all this, none of these debates are able to downplay the study into consumer impulse buying behaviour. These debates rather have generated much interest to researchers on the subject. In the light of this, a number of disciplines, such as consumer research, marketing, economics, psychology and others have attempted to define the subject.

A study by Lin and Lin (2005) defined the consumer impulse buying as unintended, immediate as well as unreflective buying circumstances. Also, Hinson et al. (2003) defined the impulse buying as a concept that prevents consumers from long-term buying consequences. In others research, Kacen and Lee (2002), impulsive consumption buying is defined as something sudden, as well as instant forceful buying behaviour. Noticeably, other studies by Stern (1962); Barley and Nancarrow (1998); Dittmar, Beattie and Friese (1995b); Iyer and Ahlawat (1987) defined the impulse buying as a decision that a buyer makes without already planned. Other researchers, Rook and Hoch (1985); Piron (1991) defined impulse buying behaviour purely as unplanned purchasing. Apart from this, Rook and Fisher (1995) defined the consumer impulsive buying behaviour as indicative of an immature, primitive, foolishness and lower intelligence. In a different study, Luo (2005), consumer impulse buying was said to be a factor within the individual capacity that encourage impulse purchases. Moreover, a research by Iris (2002) found that in most encounters it is not appropriate to relate certain purchases as impulsiveness at all. Among study, Hausman (2000), impulse buying is classified as a common approach that enables buyers to decide on products. In another study, Millner (2002) found that the consumers are hardly to shop in a rational manner. 
Additionally, researchers, D'Antoni and Shenson (1973a); Kwon and Armstrong (2002), suggested that consumer impulse purchasing as being generally accepted definition as simply as unplanned buying. This is related to consumer purchase decision that happened in-store as such. Conversely, if the consumer has entered a store with already intended purchase decisions that should be looked at as planned purchase. In a nutshell, when a consumer purchase decision is made in-store that should be seen as unplanned or impulse buying. Again, Rook (1987) defined impulse buying as immediate consumers' response towards urge to buy products. Also, another study by Weinberg and Gottward (1982) claimed that impulse buying behaviour being characterised by emotions with regard to purchase decisions.

A research by Peck and Childers (2006) revealed that consumer impulsive buying behaviour is influenced by the individual and touch-related factors within the environment at the point of purchase, and other study by Zhou and Wong (2004) indicated that impulse buying behaviour has been associated with the in-store posters advertisement, in terms of promoting discount and cheaper prices for items, as well as in-store atmosphere influenced impulsive buying behaviour, and a similar studyshows that retail operators do attract consumers towards impulse buying by giving special offer to consumers, such as 2 items for 1 item's price (Thompson, 2008). Also, Omar and Kent (2001) indicated that the shoppers' behaviour is affected by the impulse consumption buying decision. Again, Park and Lennon (2006) revealed the relations between impulse consumption buying behaviour and integration of television and retail arrangements, as well as TV shopping programmes. More so, Zhang and Shrum (2009); Luo (2005) discovered that the presence of peers is motivated by the consumer impulse consumption buying decisions. Apart from this, Weinberg and Gottward (1982) found that consumer higher emotion is found to be related to the consumer impulse buying behaviour. In addition, Sneath, Lacey and Kennett-Hansel (2009) examined that victim of disaster found making impulse buying decision. Other study by Zhang et al. (2010) identified that distance of power belief is found to be affected by the consumer impulsive purchasing decision.

Again, other studies by Sharma, Sivakumarann and Marshall (2010); Hofmann, Friese and Strack (2009) discovered that consumer impulse buying behaviour has been associated with the stimulation tendency on the part of consumers seeking for a variety of items. In addition, studies by Carrie, Ambar and Kent (2002); Clifford (2006); Thomas and Garland (2004); Sengupta and Zhou (2007); Liao, Shen and Chu (2009); Iris (2002) claimed that the uses of surprise in-store promotion, such as coupons impacted on the consumer impulsive buying decision making. Other researches, Dittmar, Beattie and Friese (1995a); Coley and Burgess (2003) indicated that both gender - men and women have been associated with making impulse buying decisions, though their selection decision differs. Males impulsively decide on instrumental and leisure items, while females impulsively decide on symbolic and self-expressive products. Also, Hinson, Jameson and Whitney (2003); Wood (1998) indicated that consumer impulsive buying is strongly associated with the dysexecutive function, as well as discounting of delayed behaviour. Moreover, Iyer and Ahlawat (1987) revealed that, a combination of factors, such as time pressure and prior knowledge of the arrangement of store layout affect the consumer original shopping objectives.

Furthermore, Baumeister (2002) stated that lack of self-control is discovered which influences impulsive purchasing behaviour. Apart from this, Dawson and Kim (2010); Dawson and Kim (2009); de Kervenoael, Aykac and Palmer (2009); Floh \& Madlberger (2007) discovered that retailers selling on web-sites, as well as the rate of external cues on the web-sites impact on impulsive buying decisions. That notwithstanding, Park, Kim and Forney (2006) revealed that, the tendency of consumer desire in fashion products in line with attached emotions is affected by impulsive buying decision making. Also, Harmancioglu, Finney and Joseph (2009); Phau and Lo (2004) found that the rate at which consumers expressed desire for new product lead to the tendency of the impulse consumption buying decision. In other study, Tucker (2008) revealed that consumers with ego-depleted position are considered much simpler to make impulse buying decision. In a different dimension, Vohs and Faber (2007) disclosed that consumers with much resource encouraged by spending more money in relation to unanticipated buying encounter.

More so, Beatty and Ferrell (1998) discovered that time available, money available, individual differences, as well as borrowing circumstances by affected by consumer impulse buying decision. Also, a study by Kwon and Armstrong (2002) indicated that consumer impulse buying behaviour has been engendered by the identity of products. In addition, Mattila and Wirtz (2008) found that the higher tendency of stimulation is affected by consumer consumption impulse buying. In a different dimension, Silvera et al. (2008) argued that cognitive aspect related to consumer's failure to plan, as well as consumer's feeling of excitement is affected by consumer impulse buying behaviour. Among study, Minjeong and Johnson (2009) concluded that both apparel return products and return policies significantly affect consumers' impulse buying decision. Among researchers, Mead, 
Vohs and Baumeister (2007) showed that the consumer social exclusion mood impact on impulse buying decision. Again, Stilly, Inman and Wakefield (2010) identified that the in-store circumstance is affected by the consumers' desire to deviate from their planned buying arrangement and a related studies, Standford (2010); Skallerud, Korneliussen and Olsen (2009) found that the convenience of stores are contributed to the consumer impulse buying. Other study by Watkins (1984) showed that more of the consumer routinised buying behaviour arrangements make up pre-planning. Also, Chatzidakis, Smith and Hibbert (2009) indicated that the consumer impulse buying behaviour is influenced by the theory of neutralisation. In other study, Anon (1996), consumer genetics has been discovered to relate to consumer impulse buying behaviour.

In addition, John (1951) discovered that both food and cosmetic items are likely to be purchased impulsively by consumers. In other research, Youn and Faber (2000) discussed that the environmental / sensory impacted on consumer impulse buying tendencies. Also, Davis and Sajtos (2009) found that, the consumer consumption buying with the use of mobile short-message-sending services, have an effect on impulse consumption buying tendency. Moreover, Jones et al. (2003) revealed that, the consumer involvement makes crucial impact in terms of buying a particular product category impulsively. More so, National Petroleum News (2007) indicated that consumer in-store self-checkout moment have an effect on impulse purchases decision, and a studies Clover (1950); Park et al. (1989) found that the two elements: (1) store knowledge, and (2) time available impact on consumer shopping behaviour impulsively.

Accordingly, Bellenger, Robertson and Hirschman (1978); Stern (1962) categorised unplanned buying into four groups: Firstly, pure impulse buying; this is a situation where a consumer sees the product and immediately buys it. Secondly, reminder impulse buying; this is a situation where a buyer sees the product and only memorizes what form around buying decision, such as previous personal knowledge. Thirdly, suggestion impulse buying; this is a situation where a buyer sees the item for the first time; reflect on it and informed purchase decision. Finally, planned impulse buying; this is whereby a buyer enters a shop with a number of already precise buying in mind, but with other alternative purchases upon the in-store atmosphere. Among study, Stern (1962) argued that impulse buying represents a significant aspect of consumer buying behaviour and marketers needs to be anticipated likely changes in the market for such products. Other researchers, Bellenger et al. (1978) showed that it is impossible to isolate and label some products as impulse products. This is because consumer buying behaviour motivation varies, such as financial strength, product information level, environmental conditions and time constraints. Furthermore, Maclnnis and Patrick (2006) research has attributed consumer impulse buying behaviour to factors such as lack of awareness and concrete relationship. In a study by Bayley and Nancarrow (1998) showed that impulse buying behaviour has been associated to a number of characteristics; such as overwhelming feeling, intense feeling and other factors, and similar study by Millner (2002) discovered that impulse buying is attributed to conditional purchases.

Furthermore, Rook and Fisher (1995) stated that, impulse buying behaviour should be seen as positively a sanctioned behaviour, for instance a buyer making quick decision to buy item for a sick person. Other study by Kollat and Willet (1967) concluded that consumers' consumption impulse buying has been attributed most frequently to food purchasing decisions. Among study, Kollat and Willet (1969) identified some products as impulse items, because such products are commonly purchase impulsively, and unplanned purchasing is not confined to any specific product or retail shop. Other researchers, Dittmar et al. (1995b) identified that two set of preferences can be related to impulsive buying consumption behaviour; (1) myopic set, which considered pushing buyers towards purchases (2) far-sighted set, which consider remembering buyers that a bill must be settled. But interestingly, neither myopic set nor far-sighted set could be concluded that it is more related to consumer impulse buying. Similarly, the study discovered two psychological approaches of the impulsive buying behaviour; Firstly, cognitive approach; it has been considered to be a major factor of impulse control in general. Secondly, clinical approach; clinical approach has been related to addictive impulse buying behaviour (Dittmar et al., 1995b).

\subsection{Antecedent of Impulse Buying Behaviour}

The literature review has shown the significance attached to impulse buying behaviour by a number of researchers. Providing this, the study explained the importance of product related attributes toward impulsive buying behaviour;

\subsubsection{Product Physical Quality}

According to Bental and Spiegel (1995), quality is seen as physical attributes that is embodied in each unit of product by the consumers. In addition, Grewal (1995) found that product physical quality has been considered as crucial in determining the achievement of a product. In a nutshell, physical qualities affect the sales of products. 
Again, Sparks and Legault (1993) explained that physical quality present a sum total of satisfaction to consumers, as well as provide a link to both manufacturers and consumers. It has been further study indicates that product physical quality has been essentially evaluated and assessed by the consumers.

\subsubsection{Product Price}

Accordingly, Rosen (2008) disclosed that consumption buying behaviour is usually centred on consumer to consider the less expensive or cheap items. Also, Lichtenstein, Ridway and Netemeyer (1993) concluded that product price represents most market place cues. It does represent all consumers engaged in given purchase transaction. Again, Buckline, Gupta and Siddarth (1998) found that combination of product price and promotional activities usually impact on the consumer's buying decision. More so, Product price is commonly considered as important determinant of the consumer store choice decision (Bell \& Lattin, 1998). Many consumers have been more sensitive to product price towards buying decisions (McCarville, 1996).

\subsubsection{Product Attractiveness}

De Angelis and Carpenter (2010) revealed that consumers make important calculations with regards to weighing benefits and costs associated with product features when making choice decisions. Also, Debby and Nelson (2006) identified that, the characteristics of product such as attractiveness of colour, normative colour, as well as colour preferences has been significantly associated with the consumer's buying decision making. Additionally, product attractiveness plays a significant effect on gender buying decision making. The physical attractiveness can highly impact on consumer decision making (WordiQ.com, 2010).

\subsubsection{Product Origin}

According to Piron (2000), product origin constitutes strong effect on products towards consumer consumption buying decision making. Also, Khan and Bamber (2008) concluded that product origin has been considered as an important factor in presenting information to consumer purchase decisions, and a related study shows that consumers give much attention to product origin in their selection with respect to buying decision making process (McCutcheon, Bruwer, \& Li, 2009). Again, Johnson (2005), product origin influenced consumers' decision on products towards consumption buying event.

\subsubsection{Purchase Location}

Charkchian and Daneshpour (2009) discovered purchase location as varying physical, social and meaning characteristics that shows where consumers make buying decisions towards products. The physical location represents the retail stores, such as small retail stores, departmental stores, and large super market shops (Ohio Revised, 1961). Physical factor influences where consumers make choice of buying product. As a result, consumers take into considerations transport cost, as well as environmental location when making buying decision (Eufic Review, 04/2005).

\section{Methodology}

\subsection{Data Collection and Analyses}

The researchers initially samples the number of small retail stores, departmental stores, super market shops, and shopping malls in the City of Accra, and selected Accra Shopping Mall (Shop Rite) which consists of almost every shop. Accordingly, the researchers selected 200 population for this study both male and female who was between ages of 18-46+ that visit the Mall and literate. The literate respondents were considered; this is simply because this type of category of population ease the administration of survey questionnaire since it was self-administered and designed in English Language only. In this regard, the researchers distribute 200 survey questionnaires; whilst 179 questionnaires were retrieved. The study employed convenience sampling method (non-probability sampling method). All distribution and collection work were carried out by the researchers (Malhotra \& Birks, 2003, pp. 358-360). In order to ease the distribution and collection of a survey questionnaire, and since respondents only come to the Mall to shop and leave. Again, the researchers were been guided that all questionnaires distributed were completed at the point of taken and hand-in; that is focus mainly on respondents that shows commitment, as well as interest to help. Hence, distribution and collection mainly carried out as a result of visit premises of the Mall, typically, the two main entrance of the Mall, as well as visit the car park of the Mall, and sometimes visited places like different restaurants \& bars inside the Mall. The researchers did not make any attempt to interrupt anyone at the point of purchase or searching for an items (to buy); as it would have been considered as the invade of privacy or against research ethics (Malhotra \& Birks, 2003, pp. 24, 416). On the whole, the study lasted for 23 days - for distribution and collection of survey instruments. There were "NO" form of attempt by the researchers to persuade or offer incentives to any respondents. Additionally, there were "NO" form of chase non-respondents. The respondents' contribution to this study was done through free will. 
Hence, the respondents' contribution to this research was appreciated through thanks given (Malhotra \& Birks, 2003, p. 416).

Significantly, the researchers employed the used of the structured designed survey questionnaire, in order to obtain information of the consumers experience with regard to the impulse buying. The researchers conducted pilot study; this is simply because the researchers' aim is to produce data that is valid, reliable and unbiased (Collins, 2003). The questionnaires consists of closed ended questions; make up fixed response answers to be selected, and some, other space specified for the respondent(s) to factor any alternative answer(s) of their own choice (Malhotra \& Birks, 2003, p. 224). The survey questionnaire were in three main Parts-Part: A, B and C. Part A of the questionnaire contained information on the demographic of the respondents; Gender, Age and Education Level; Part B was related to consumer impulse buying behaviour; whether respondents buy products unplanned, in a typical month how many times they buy products unplanned, product they buy unplanned most, how they tend to change the way they buy products unplanned. Part $\mathrm{C}$ of the questionnaire used 5-point interval Likert rating measurement scale where $1=$ Strongly Agree; $2=$ Agree; $3=$ Neutral; $4=$ Disagree; $5=$ Strongly Disagree. Overall, the three parts of the questionnaire designed adopted from Malhotra and Birks (2003, pp. 224-225; 358-360); Walonick (1993).

The data collected were entered for analysis and evaluation with the use of Statistical Package for Social Sciences (SPSS), Version 17. The main analysis for this study is based on measuring the association between the consumer impulse buying behaviour from a range of consumer and product physical quality, product price, product attractiveness, product origin, and purchase location. Significantly, based on the data collected, the researchers (clearly) uses nominal scale measurement, which allows each or individual variable to be categorised (categorical data) into specific clusters or groups (Malhotra \& Birks, 2003, p. 294). As a result, a crosstabulation statistical technique is employed. This is simply because crosstabulation frequencies constitute fundamental technique that allow to measure association between two categorical variables. Noticeably, the measures displayed totals count of row and column (including computation percentages) of frequencies on the two variables of each of the five research questions set. Apart from this, it is important to mention that crosstabulation frequencies alone could not produce sufficient results (but produce analysis that set pace for deeper analysis). The crosstabulation frequencies gives blend of the respondents responses of the variables measured. In this case, the researchers did not make attempt to discuss details crosstabulation frequencies results in relations to measure of the association between two variables (Malhotra \& Birks, 2003, pp. 457-458, 463). However, since there are a number of statistics available in the crosstabulation procedure- that is, for $2 \times 2$ tables (two rows and two columns), the most commonly used is the phi coefficient, which is a correlation coefficient and can range from 0 to 1 (Malhotra \& Birks, 2003, p. 466). In the light of this, for tables larger than $2 \times 2$ (two rows and two columns), such as this (current) study analysis, the value to report is Cramer's V, which takes into account the degrees of freedom in measuring the association. The range of values used for assessing the strength of association is $0-1$, when the values 0 -means no association, $0.1-0.2$ weak association, $0.3-0.5$ fairly strong association, $0.6-0.7$ strong association, $0.8-0.9$ very strong association and, 1-perfect association (Malhotra \& Birks, 2003, p. 466; Pallant, 2007, p. 283).

\section{Research Findings}

Table 1 shows the total number of 179 respondents, 111 respondents $(62.0 \%)$ were males, whereas 68 respondents $(38.0 \%)$ were females. The age of respondents; 34 respondents $(19.0 \%)$ were between the ages of 18-24. 99 respondents $(55.3 \%)$ they fell between the ages of $25-34$; with 41 respondents $(22.9 \%)$ were found to be between $35-45$, and the ages of $46+, 5$ respondents $(2.8 \%)$. With the education level of respondents; 6 respondents $(3.4 \%)$ make up those with secondary education level, 16 respondents $(8.9 \%)$ make up those with college education level (i.e. those with non-tertiary level/qualification, such as teacher training college, nursing training college, and so on), 134 respondents (74.9\%) make up those with tertiary education level (i.e., those with polytechnic and university 1 st degree level/qualification), 12 respondents $(6.7 \%)$ make up those with higher education level (i.e., those with masters' and doctorate level/qualification) and 11 respondents (6.1\%) specified other of education level. 
Table 1. Demographic profile of respondents

\begin{tabular}{lll}
\hline Demographic & Frequency & Percentage \\
\hline Gender & & \\
Male & 111 & $62 \%$ \\
Female & 68 & $38 \%$ \\
\hline Age & & \\
$18-24$ & 34 & $19.0 \%$ \\
$25-34$ & 99 & $55.3 \%$ \\
$35-45$ & 41 & $22.9 \%$ \\
$46+$ & 5 & $2.8 \%$ \\
\hline Education Level & & \\
Secondary & 6 & $3.4 \%$ \\
College & 16 & $8.9 \%$ \\
Tertiary & 134 & $74.9 \%$ \\
Higher & 12 & $6.7 \%$ \\
Other & 11 & $6.1 \%$ \\
\hline
\end{tabular}

Table 2 presents the analysis of the consumer impulse buying behaviour. Out of the 179 respondents, 60 respondents $(33.5 \%)$ make up in a typical month 1 to 2 times of those that buy products unplanned, 56 respondents $(31.3 \%)$ make up in a typical month 2 to 3 times of those that buy products unplanned, 22 respondents $(12.3 \%)$ make up in a typical month 3 to 4 times of those that buy products unplanned, and 41 respondents $(22.9 \%)$ make up in a typical month more than 5 times of those that buy products unplanned. Also, the product purchased unplanned, 72 respondents $(40.2 \%)$ represent those that buy clothes, 19 respondents $(10.6 \%)$ represent those that buy soft drink, 2 respondents $(1.1 \%)$ represent those that buy alcoholic drink, 24 respondents $(13.4 \%)$ represent those that buy cosmetic items, 10 respondents $(5.6 \%)$ represent those that buy shoes, 49 respondents $(27.4 \%)$ represent those that buy food items, 3 respondents $(1.7 \%)$ represent those that buy other items.

Table 2. Consumer impulse buying behavior

\begin{tabular}{lcc}
\hline \multicolumn{3}{l}{ Consumer Impulse Buying Behaviour Frequency Percentage } \\
\hline \multicolumn{2}{l}{ Times Consumer Buy Product Impulsively } \\
1 to 2 times & 60 & $33.5 \%$ \\
2 to 3 times & 56 & $31.3 \%$ \\
3 to 4 times & 22 & $12.3 \%$ \\
More than 5 times & 41 & $22.9 \%$ \\
\hline Product Buy Unplanned Most & & \\
Clothes & 72 & $40.2 \%$ \\
Soft drink & 19 & $10.6 \%$ \\
Alcoholic drink & 2 & $1.1 \%$ \\
Cosmetic items & 24 & $13.4 \%$ \\
Shoes & 10 & $5.6 \%$ \\
Food items & 49 & $27.4 \%$ \\
Other & 3 & $1.7 \%$ \\
\hline
\end{tabular}

\subsection{Association Analysis}

Measure of association between the consumer impulse buying behaviour from a range of consumer and product related factors

Table 3. Measures of association

\begin{tabular}{llll}
\hline & & Value & Approx. Sig. \\
\hline Nominal by Nominal & Phi & .252 & .180 \\
& Cramer's V & .178 & .180 \\
N of Valid Cases & & 179 & \\
\hline
\end{tabular}


Table 3 depicts Cramer's V statistics used to measure the association between the consumer impulse buying behaviour from a range of consumer and product physical quality. From table 3, it can be noted that about 0.178 Cramer's V indicates weak association between the consumer impulse buying behaviour from a range of consumer and product physical quality.

Table 4. Measures of association

\begin{tabular}{llll}
\hline & & Value & Approx. Sig. \\
\hline Nominal by Nominal & Phi & .267 & .199 \\
& Cramer's V & .189 & .199 \\
N of Valid Cases & & 179 & \\
\hline
\end{tabular}

Table 4 shows Cramer's V statistics used to measure the association between the consumer impulse buying behaviour from a range of consumer and product price. It can be observed from table 4 that about 0.189 Cramer's V shows weak association between the consumer impulse buying behaviour from a range of consumer and product price.

Table 5. Measures of association

\begin{tabular}{llll}
\hline & & Value & Approx. Sig. \\
\hline Nominal by Nominal & Phi & .272 & .104 \\
& Cramer's V & .192 & .104 \\
N of Valid Cases & & 179 & \\
\hline
\end{tabular}

Table 5 shows Cramer's V statistics used to measure the association between the consumer impulse buying behaviour from a range of consumer and product attractiveness. From table 5, it can be seen that there is about 0.192 weak association between the consumer impulse buying behaviour from a range of consumer and product attractiveness.

Table 6. Measures of association

\begin{tabular}{llll}
\hline & & Value & Approx. Sig. \\
\hline Nominal by Nominal & Phi & .283 & .074 \\
& Cramer's V & .200 & .074 \\
N of Valid Cases & & 179 & \\
\hline
\end{tabular}

Table 6 shows Cramer's V statistics used to measure the association between the consumer impulse buying behaviour from a range of consumer and product origin. From table 6, it indicates that there is very weak association of about 0.200 between the consumer impulse buying behaviour from a range of consumer and product origin.

Table 7. Measures of association

\begin{tabular}{llll}
\hline & & Value & Approx. Sig. \\
\hline Nominal by Nominal & Phi & .345 & .006 \\
& Cramer's V & .244 & .006 \\
N of Valid Cases & & 179 & \\
\hline
\end{tabular}

Table 7 shows Cramer's V statistics used to measure the association between the consumer impulse buying behaviour from a range of consumer and purchase location. From table 7, it indicates that there is very weak association of about 0.244 between the consumer impulse buying behaviour from a range of consumer and purchase location. 


\subsection{Discussion of Research Findings}

The findings, times consumers buy products support the view that the consumer impulse buying behaviour has actually been a very rare behaviour, and its represent a significant form of consumption buying behaviour (see Cobb \& Hoyer, 1986; Iris, 2002). Additionally, the findings support the assertion that impulse buyer represents a significant aspect of consumer consumption buying behaviour and needs to be anticipated likely changes in the market for such products (see Stern, 1962). However, the findings are not consistent with the view that the American consumers' are mainly attributed to consumption impulse buying in relations to their lifestyles (see Rook, 1987).

Also, the findings revealed that when it comes to unplanned buying of product which is consistent with the findings of study (see Kollat \& Willet, 1969). It is further revealed that consumer involvement makes a crucial impact in terms of buying a particular product category impulsively (see Jones et al., 2003). Furthermore, these findings support the assertion that it is impossible to isolate and label some products as impulse products. This is because consumer buying behaviour, motivation variables, such as financial strength, product information level, environmental conditions and time constraints (see Bellenger et al., 1978). However, the findings are not consistent with the assertion that both food and cosmetic items are likely to be purchased impulsively by the consumers (see John, 1951). Also, the findings do not support the assertion that the consumers' consumption impulse buying is attributed most frequently to the food purchasing decision (see Kollat \& Willet, 1967).

The findings of this study shows that when it comes to consumer impulse buying behaviour, product physical quality which has weak association and some extent is consistent with the findings of work (see Bental \& Spiegel, 1995; Grewal, 1995; Sparks \& Legault, 1993; Swartz \& Brown, 1989). Another findings in this study discovered that when it comes to impulse buying behaviour, product price has weak association, to some extent is consistent with the findings of study (see Rosen, 2008; Lichtenstein et al., 1993; Buckline et al., 1998; Bell \& Lattin, 1998; McCarv2ille, 1996). Furthermore, the finding revealed that when it comes to impulse buying behaviour, product attractiveness has similar weak association, to some level is in line with the findings of work (see De Angelis \& Carpenter, 2010; Debby \& Nelson, 2006; WordiQ.com, 2010). In addition, the finding revealed that when it comes to impulse buying behaviour, product origin has weak association and it has some aspect of consistent with the findings of study (see Piron, 2000; Khan \& Bamber, 2008; McCutcheon et al. 2009; Johnson, 2005). Finally, the finding in this study revealed that when it comes to impulse buying behaviour, purchase location has weak association and some extent is consistent with the findings of work (see Charkchain \& Daneshpour, 2009; Ohio Revised (1961); Eufic Review, 04/2005).

\section{Conclusion}

Overall, finding results show that, the association between consumer impulse buying behaviour and product physical quality, product price, product attractiveness, product origin and purchase location was not strong. Consequently, the detailed analyses showed by each of the (five) research questions indicated that; the association between the consumer impulse buying behaviour from a range of consumer and product physical quality was found weak. In the same vein, the association between the consumer impulse buying behaviour from a range of consumer and product price was found weak and the association between the consumer impulse buying behaviour from a range of consumer and product attractiveness was also found weak. In addition, the association between the consumer impulse buying behaviour from a range of consumer and product origin was found very weak. It has further noted also that the association between the consumer impulse buying behaviour from a range of consumer and purchase location was found very weak. Despite the results which have shown the weak association, to some extent there is association between the consumer impulsive buying behaviour and product related factors.

\section{References}

American Marketing Association. (1969). Is Impulse Purchasing Really a Useful Concept for Marketing Decisions? Journal of Marketing, 33(1), 79-83. https://doi.org/10.2307/1248750

Anon. (1996). Scientists identify gene linked to impulsive traits. Wall Street Journal-Eastern Edition, $227(1), 16$.

Baumeister, R. E. (2002). Yielding to Temptation: Self-Control Failure, Impulsive Purchasing, and Consumer Behaviour. Journal of Consumer Research, 28(4), 670-676. https://doi.org/10.1086/338209

Bayley, G., \& Nancarrow, C. (1998). Impulse purchasing qualitative exploration of the phenomenon. Qualitative Market Research: An International Journal, 1(2), 99-114. http://dx.doi.org/10.1108/13522759810214271

Beatty, S. E., \& Farrell, M. E. (1998). Impulse buying: Modelling its Precursors. Journal of Retailing, 74(2), 169-191. http://dx.doi.org/10.1016/S0022-4359(98)90009-4 
Bell, D. R., \& Lattin, J. M. (1998). Shopping Behavioural Consumer Preference for Store Price Format: Why "Large Basket" Shoppers Prefer EDLP. Marketing Science, 17(1), 66-88. http://dx.doi.org/10.1287/mksc.17.1.66

Bellenger, D. N., Robertson, D. H., \& Hirschman, E. C. (1978). Impulse Buying Varies by Product. Journal of Advertising Research, 18(6). http://dx.doi.org/10.12691/jbms-3-2-3

Bental, B., \& Spiegel, M. (1995). Network Competition, Product Quality, and Market Coverage in the Presence of Network Externalities. Journal of Industrial Economies, 43(2). http://dx.doi.org/0022-1821

Buckline, R. E., Gupta, S., \& Siddarth, S. (1998). Determining Segmentation in Sales Response Across Consumer Purchase Behaviours. Journal of Marketing Research, 35(2), 189-197. https://doi.org/10.2307/3151847

Carrie, M. H., Ambar, G. R., \& Kent, N. (2002). Pleasant Surprises: Consumer Response to Unexpected In-Store Coupons. Journal of Marketing Research, 39(2). http://dx.doi.org/10.1509/jmkr.39.2.242.19081

Charkhchian, M., \& Daneshpour, S. A. (2009). Interactions among Different Dimensions of a Responsive Public Space: A Case Study in Iran. Review of Urban and Regional Development Studies, 21(1), 14-36. https://doi.org/10.1111/j.1467-940X.2009.00157.x

Chatzidakis, A., Smith, A. P., \& Hibbert, S. (2009). Do I need it, do I, do I really need this? Exploring the Role of Rationalisation in Impulse Buying Episodes. Advances in Consumer Research-North American Conference Proceedings, 36, 248-253.

Clifford, S. (2006). A golden window for impulsive buying. Inc., 28(4), 32-32.

Clover, V. T. (1950). Relative Importance of Impulse-buying in Retail Stores. Journal of Marketing, 15(1). https://doi.org/10.2307/1247083

Cobb, C. J., \& Hoyer, W. B. (1986). Planned versus Impulse Purchase Behaviour. Journal of Retailing, 62(4).

Coley, A., \& Burgess, B. (2003). Gender differences in cognitive and affective impulse buying. Journal of Fashion Marketing and Management, 7(3), 282-295. http://dx.doi.org/10.1108/13612020310484834

Collins, D. (2003). Presenting survey instruments: an overview of cognitive methods, Quality of Life Research. International Journal of Quality of Life Aspects of Treatment Care and Rehabilitation, 12(3), 229-238. https://doi.org/10.1023/A:1023254226592

D’Antoni Jr. S., \& Shenson, H. L. (1973a). Impulse Buying Revisited: A Behavioural Typology. Journal of Retailing, 49(1), 63.

D’Antoni Jr., J. S., \& Shenson, H. L. (1973b). Impulse Buying Revisited: A Behavioural Typology. Journal of Retailing, 49(1), 63.

Davis, R., \& Sajtos, L. (2009). Anytime, Anywhere: Measuring the ubiquitous consumer's impulse purchase behavior. International Journal of Mobile Marketing, 4(1), 15-22.

Dawson, S., \& Kim, M. (2009). External and internal trigger cues of impulse buying online; Direct Marketing. International Journal of Marketing, 3(1), 20-24. http://dx.doi.org/10.1108/17505930910945714

Dawson, S., \& Kim, M. (2010). Cues on apparel web sites that triggers impulse purchases. Journal of Fashion Marketing and Management, 14(2), 230-246. http://dx.doi.org/10.1108/13612021011046084

De Angelis, M., \& Carpenter, G. S. (2010). The effects of Adding Feature on Product Attractiveness: The Role of Product Perceived Congruity.

De Kervenoael, R., Aykac, D. S. O., \& Palmer, M. (2009). Online social capital: understanding e-impulse buying in practice. Journal of Retailing \& Consumer Service, 16(4), 320-328. http://dx.doi.org/10.1016/j.jretconser.2009.02.007

Debby, F., \& Nelson, O. N. (2006). Colour and product choice: a study of gender roles. Management Research News, 29(1/2), 41-52.

Dittmar, H., Beattie, J., \& Friese, S. (1995a). Gender identity material symbols: objects and direction considerations in impulse purchases. Journal of Economic Psychology, 16(3), 491-511. http://dx.doi.org/10.1016/0167-4870(95)00023

Dittmar, H., Beattie, J., \& Friese, S. (1995b). Objects, Decision Considerations and Self-image in Men's and Women's Impulse Purchases. 
Eufic Review. (04/2005). The Determinants of Food Choice.

Floh, A., \& Madlberger, M. (2007). Measuring the Antecedents of Impulsive Buying Behaviour on the WWW. Advances in Consumer Research-North American Conference Proceedings, 34, 403-404.

Grewal, D. (1995). Product Quality Expectations: Towards an understanding of their Antecedents and Consequences. Journal of Business Psychology, 9(3). https://doi.org/10.1007/BF02230967

Harmancioglu, N., Finney, R. Z., \& Joseph, M. (2009). Impulse Purchases of new Products; an empirical $\begin{array}{llll}\text { analysis. Journal of Product \& Brand Management, } 18(1), & \text { 27-37. }\end{array}$ http://dx.doi.org/10.1108/10610420910933344

Hausman, A. (2000). A multi-method investigation of consumer motivations in impulse buying behavior. Journal of Consumer Marketing, 17(5), 403-426. https://doi.org/10.1108/07363760010341045

Hinson, J. M., Jameson, T. L., \& Whitney, P. (2003). Impulsive Decision Making and Working Memory. Journal of Experiment Psychology/Learning, Memory \& Cognition, 29(2), 298-306. https://doi.org/10.1037/0278-7393.29.2.298

Hoch, S. J., \& Loewentein, G. F. (1991). Time-inconsistent Preferences and Consumer Self-Control. Journal of Consumer Research, 17(4), 492-507. https://doi.org/10.1086/208573

Hofmann, W., Friese, M., \& Strack, F. (2009). Impulse and Self-Control from a Dual-Systems Perspective. Journal of the Association for Psychological Science, $4(2)$. https://doi.org/10.1111/j.1745-6924.2009.01116.x

Iris, I. M. (2002). In-store impact on impulse shoppers. Marketing, p. 27.

Iyer, E. S., \& Ahlawat, S. A. (1987). Deviation from a Shopping Plan: when and Why do Consumers not Buy items as Planned. Advance in Consumer Research, 14(1), 246-250.

John, C. (1951). Results of Two Years of Study into Impulse Buying. Journal of Marketing, 15(3), 362-363. https://doi.org/10.2307/1247377

Johnson, K. F. (2005). The automatic Country-of-Origin effects on brand judgement. Journal of Advertising, p. 1.

Jones, M. A., Reynolds, K. E., Weun, S., \& Beatty, S. E. (2003). The product-specific nature of impulse buying tendency. Journal of Business Research, 56(7), 505. http://dx.doi.org/10.1016/S0148-2963(01)00250-8

Kacen, J. J., \& Lee, J. A. (2002). The Influence of Culture on Consumer Impulsive Buying Behaviour. Journal of Consumer Psychology, 12(2), 163-176. https://doi.org/10.1207/S15327663JCP1202_08

Khan, H., \& Bamber, D. (2008). Country of Origin effects, brand image, and social status in an emerging market. International Journal of Human Factors in Manufacturing, 18(5), 580-588. https://doi.org/10.1002/hfm.20126

Klaus, W. (1998). Consumption Self-control by Rationing Purchase Quantities of Virtue and Vice. Marketing Science, 17(4).

Kollat, D., \& Willet, R. (1969). Is Impulse Purchasing Really a Useful Concept for Marketing Decisions? Journal of Marketing, 33(1), 79-83. https://doi.org/10.2307/1248750

Kollat, D., \& Willett, R. (1967). Customer Impulse Purchasing Behaviour, Journal of Marketing Research, 4(1), 21-31. https://doi.org/10.2307/3150160

Kwon, H. H., \& Armstrong, K. L. (2002). Factors Influencing Impulse Buying of Sport Team Licensed Merchandise. Sport Marketing Quarterly, 11(3), 151.

Liao, S., Shen, L., \& Chu, C. (2009). The effects of sales promotion strategy, product appeal and consumer traits on reminder impulse buying behavior. International of Consumer Studies, 33(3), 274-284. https://doi.org/10.1111/j.1470-6431.2009.00770.x

Lichtenstein, D. R., Ridway, N. M., \& Netemeyer, R. G. (1993). Price Perceptions and Consumer Shopping Behaviour: A Field Study. Journal of Marketing Research, 30(2), 234-245. https://doi.org/10.2307/3172830

Lin, C., \& Lin, C. (2005). An exploration of Taiwanese adolescents' impulsive buying tendency.

Luo, X. (2005). How Does Shopping with others Influence Impulsive Purchasing? Journal of Consumer Psychology, 15(4), 288-294. http://dx.doi.org/10.1207/s15327663jcp1504_3

MacInnis, D. J., \& Patrick, V. M. (2006). Spotlight on Affect: Affect and Affective Forecasting in Impulse 
Control. Journal of Consumer Psychology, 16(13), 22-231. https://doi.org/10.1207/s15327663jcp1603_4

Malhotra, K., \& Birks, F. (2003). Marketing Research. Harlow: Pearson Education Limited.

Mattila, A, S., \& Wirtz, J. (2008). The role of store environmental stimulation and social factors on impulse purchasing. Journal of Service Marketing, 22(7), 562-567. http://dx.doi.org/10.1108/08876040810909686

McCarville, R. E. (1996). The Importance of Price Last Paid in Developing Price Expectations for a Public Leisure Service. Journal of Park and Recreation Administration, 4(4), 52-64.

McCutcheon, E., Bruwer, J., \& Li, J. (2009). Region of origin and its importance among choice factor in the wine-buying decision making of consumers. International Journal of Wine Business Research, 21(3), 212-234. https://doi.org/10.1108/17511060910985953

Mead, N., Vohs, K., \& Baumeister, R. (2007). Does a Broken Heart Lead to an Empty Wallet? Social Exclusion Affects Impulsive Spending. Advances in Consumer Research, 34, 411-412.

Millner, I. (2002). Burying the myth of impulse buying. Brand Strategy, 163, 38.

Minjeong, K., \& Johnson, K. (2009). Identifying characteristics of consumers who frequently return apparel. Journal of Fashion Marketing and Management, 13(1), 37-48. https://doi.org/10.1108/13612020910939860

National Petroleum News. (2007). Women Could Lose 4.1 Pounds Simply by avoiding impulse items at the checkout. I H L Consulting Group Study, 99(10), 8-8.

Ohio Revised. (1961). LAwriter Ohio Law and Rules: Retail Instalment Sale Definitions.

Omar, O., \& Kent, A. (2001). International airport influences on impulsive shopping: trait and normative approach. International Journal of Retail \& Distribution Management, 29(5), 226-235. http://dx.doi.org/10.1108/09590550110390887

Pallant, J. (2007). SPSS Survival Manual. McGrow-Hill: McGrow-Hill Open University Press.

Park, C. W., Iyer, E. S., \& Smith, D. C. (1989). The Effects of Situational Factors on In-Store Grocery Shopping Behaviour: The Role of Store Environment and Time Available for Shopping. Journal of Consumer Research, 15(4). https://doi.org/10.1086/209182

Park, E. J., Kim, E. Y., \& Forney, J. C. (2006). A structural model of fashion-oriented impulse buying behaviour. Journal of Fashion Marketing and Management, 10(4), 433-446. https://doi.org/10.1108/13612020610701965

Park, J., \& Lennon, S. J. (2006). Psychological and environment antecedents of impulse buying tendency in the multichannel shopping context. Journal of Consumer Marketing, 23(2), 56-66. https://doi.org/10.1108/07363760610654998

Peck, J., \& Childers, T. (2006). If I touch it I have to have it: Individual and environmental influences on impulse purchasing. Journal of Business Research, 59(6), 765-769. http://dx.doi.org/10.1016/j.jbusres.2006.01.014

Phau, I., \& Lo, C. (2004). Profiling fashion innovators. A study of self-concept, impulse buying and internet purchase intent. Journal of Marketing and Management, 8(4), 399-441. http://dx.doi.org/10.1108/13612020410559993

Piron, F. (1991). Defining Impulse Purchasing. Advances in Consumer Research, 18, 509-514.

Piron, F. (2000). "Consumers" Perceptions of the country-of-origin effect on purchasing intentions of (in) conspicuous products'. Journal of Consumer Marketing, 17(4), 308-321. https://doi.org/10.1108/07363760010335330

Rook, D. W. (1987). The Buying Impulse. Journal of Consumer Research, 14(2), 189-199. https://doi.org/10.1086/209105

Rook, D. W., \& Fisher, R. J. (1995). Normative Influences on Impulsive Buying Behaviour. Journal of Consumer Research, 22(3), 305-313. https://doi.org/10.1086/209452

Rook, D. W., \& Hoch, S. J. (1985). Consuming Impulses. Advances in Consumer Research, 12(1), 23-27.

Rosen, S. (2008). Hedonic Prices and Implicit Markets: Product Differentiation in Pure Competition. Journal of Political Economy, 82(1), 34-55. https://doi.org/10.1086/260169

Scribd. (2009). Qualitative and Quantitative Method of Research.

Sengupta, J., \& Zhou, R. (2007). Understanding Impulsive Eaters' Choice Behaviours: The Motivational 
Influences of Regulatory Focus. Journal of Marketing Research, 44(2), 297-308. https://doi.org/10.1509/jmkr.44.2.297

Sharma, P., Sivakumarann, B., \& Marshall, R. (2010). Impulse buying and variety seeking, Journal of Business Research, 63(3), 270-283. http://dx.doi.org/10.1016/j.jbusres.2009.03.013

Silvera, D. H., Lavack, A. M., \& Kropp, F. (2008). Impulse buying: the role of affect, social influence, and subjective wellbeing. Journal of Consumer Marketing, 25(1), 23-33. http://dx.doi.org/10.1108/07363760810845381

Skallerud, K., Korneliussen, T., \& Olsen, S. O. (2009). An Examination of Consumers' Cross-shopping Behaviour. Journal of Retailing and Consumer Services, 16(3), 181-189. https://doi.org/10.1016/j.jretconser.2008.11.012

Sneath, J., Lacey, R., \& Kennett-Hansel, P. (2009). Coping with a natural disaster: Losses, emotions, and impulsive and compulsive buying. Marketing Letters, 20(1), 45-60. http://dx.doi.org/10.1007/s11002-008-9049-y

Sparks, R. E., \& Legault, R. D. (1993). A definition of quality for total customer satisfaction: the bridge between manufacturer and customer. Advanced Management Journal, 58.

Standford, D. D. (2010). Slurping Toward an Economic Recovery. Bloomberg Business week, 4178, 23-23.

Stern, H. (1962). The Significance of Impulse Buying Today. Journal of Marketing, 26(2), 59-62. https://doi.org/10.2307/1248439

Stilly, K. M., Inman, J. J., \& Wakefield, K. L. (2010). Planning to Make Unplanned Purchases? The Role of In-Store Slack in Budget Deviation. Journal of Consumer Research. https://doi.org/10.1086/651567

Swartz, T. A., \& Brown, S. W. (1995). Consumer and Provider Expectations and Experience in Evaluating Professional Service Quality. Journal of the Academy of Marketing Science, 17(2).

Tauber, E. M. (1972). Why Do People Shop? Journal of Marketing, 36(4), 46-49. https://doi.org/10.2307/1250426

Thomas, A., \& Garland, R. (2004). Grocery shopping: list and non-list usage. Marketing Intelligence \& Planning, 22(6). http://dx.doi.org/10.1108/02634500410559015

Thompson, C. J. (2008). Three Easy Tips for Selling Impulse. Gifts \& Decorative Accessories, 109(7).

Tucker, P. (2008). Fighting the Urge to Fight the Urge. Futurist, 42(2), 11-11.

Vohs, K. D., \& Faber, R. J. (2007). Spent Resources: Self-Regulatory Resource Availability Affect Impulse Buying. Journal of Consumer Research, 33(4). bhttp://dx.doi.org/10.1086/510228

Walonick, D. S. (1993). Everything you wanted to know about questionnaires but were afraid to ask.

Watkins, T. (1984). Consumer Purchasing of Low-involvement Goods: Routine or Impulse? Marketing Intelligence \& Planning, 2(2). http://dx.doi.org/10.1108eb045700

Weinberg, P., \& Gottward, W. (1982). Impulsive Consumer Buying as a Result of Emotions. Journal of Business Research, 10(1), 43-57. https://doi.org/10.1016/0148-2963(82)90016-9

Wood, M. (1998). Socio-economic status, delay of gratification, and impulse buying. Journal of Economic Psychology, 19(3), 295-320. http://dx.doi.org/10.1016/S0167-4870(98)00009-9

WordiQ.com (2010). Physical attractiveness-Definition.

Youn, S., \& Faber, R. J. (2000). Impulse Buying: Its Relation to Personality Traits and Cues. Advances in Consumer Research, 27(1), 179-185.

Zhang, Y., \& Shrum, L. J. (2009). The Influence of Self-Construal on Impulsive Consumption. Journal of Consumer Research, 35, 838-850. https://doi.org/10.1086/593687

Zhang, Y., Winterich, K. P., \& Mital, V. (2010). Power Distance Belief and Impulsive Buying. Journal of Marketing Research, 47(5), 945-954. https://doi.org/10.1509/jmkr.47.5.945

Zhou, L., \& Wong, A. (2004). Consumer Impulse Buying and In-Store in Chinese Supermarkets. Journal of International Consumer Marketing, 16(2), 37-53. http://dx.doi.org/10.1300/J046v16n02_03 


\section{Copyrights}

Copyright for this article is retained by the author, with first publication rights granted to the journal.

This is an open-access article distributed under the terms and conditions of the Creative Commons Attribution license (http://creativecommons.org/licenses/by/4.0/). 